\title{
Introduction to the Special Issue on Military Moral Injury
}

\author{
Carrie Doehring ${ }^{1} \cdot$ Nancy J. Ramsay ${ }^{2}$
}

Published online: 19 December 2018

(C) Springer Science+Business Media, LLC, part of Springer Nature 2018

This special issue addresses spiritual care for persons affected by military moral injury. It gathers articles by Jewish, Christian, and Muslim authors who draw on their traditions to support those who offer theologically reflective, spiritually informed care with veterans and their families affected by moral injury. Spiritual care providers in faith communities, chaplains in VA hospitals, hospice, retirement, and assisted living contexts, spiritual directors, and those serving as military chaplains will especially find these articles useful.

The articles range widely across more clinically informed practices to practices based on spiritual disciplines and the use of witness poetry to facilitate lament in its confessional and ethical modes. Other articles draw on sacred texts in the Hebrew Bible that address moral injury and lament, care for moral injury through the frame of ambiguous loss, and the effective use of ritual practices to support healing. Although most of the articles focus on agential moral injury that arises from the misuse of one's agency, one article voices the pain of receptive moral injury arising from a veteran experiencing religious oppression by her Army comrades on the basis of her Muslim faith. Another looks directly at how congregations can support veterans in their recovery from moral injury. Several articles address strategies for helping civilians in faith communities become more reflective about how we may be implicated in moral injury when our countries wage war.

The origins of this issue lie in the initiative of the Soul Repair Center at Brite Divinity School, which was founded in 2012 with funding from the Lily Endowment for Religion. In its first four years, the Center was directed by Dr. Rita Nakashima Brock and Col. Herman Keizer (U.S. Army Ret.), a career military chaplain, who served as co-director until his retirement. The Center's work was at first focused on promoting public education about moral injury and fostering research that would inform effective care for veterans and their families in faith communities. In August of 2016, Dr. Nancy J. Ramsay became the Director of the Soul Repair Center. The Center's work is now focused on equipping religious leaders and faith

Carrie Doehring cdoehring@iliff.edu

Nancy J. Ramsay

n.ramsay@tcu.edu

$1 \quad$ Iliff School of Theology, 2323 E. Iliff Ave., Denver, CO 80210, USA

2 Brite Divinity School, 2855 S. University Dr., Fort Worth, TX 76129, USA 
communities responding to persons affected by military moral injury and fostering research informing such care.

In 2013, the Center initiated an interreligious pastoral theological think tank, chaired by Brite professor Dr. Nancy J. Ramsay, to generate resources for informing spiritual care with veterans and their families in faith communities. The members met for two years; each scholar or practitioner developed a distinctive resource, and the group provided responses to each other's work. In October of 2015, most of those participants led workshops and presentations at the Center's national conference in Kansas City. The think tank presenters at the conference included Dr. Dale Andrews, Dr. Carrie Doehring, Rabbi Kim Geringer, Dr. Larry Graham, Chaplain Shareda Hosein, Dr. Elizabeth Liebert, SNJM, Dr. Nancy J. Ramsay, and Rabbi Nancy Wiener, D.Min.

Following that conference, we proposed this special issue to the editor of Pastoral Psychology, Dr. Lewis Rambo, who had expressed interest in the issue from the beginning. With his encouragement, the issue began to take shape. We recruited additional contributors to enhance the range of articles and experience represented, including Shawn Fawson, PhD candidate at Iliff School of Theology/Denver University, whose work with witness poetry informs spiritual care, Dr. Zachary Moon, a reservist military chaplain and seminary professor, and Reverend Michael Yandell, a veteran who identifies as experiencing moral injury and whose research as a $\mathrm{PhD}$ candidate in theology at Emory University explores moral injury. We had hoped to include an article by Dr. Larry Kent Graham, whose pioneering work in practical theology exploring the impact of war on families inspired many of us. Dr. Graham's untimely death prevented him from completing a contribution on lamentation-a generative aspect of recovery that many of our authors referenced in using Dr. Graham's scholarship.

Publisher's Note Springer Nature remains neutral with regard to jurisdictional claims in published maps and institutional affiliations. 